\title{
Authenticity of the Basotho Hat: Perceptions of Weavers and Vendors
}

\author{
Haretsebe Manwa (PhD) \\ Tourism Department, North West University, Private Bag X2046, Mmabatho, South Africa, 2735 \\ Email:23815310@nwu.ac.za or hamanwa@yahoo.com.au
}

\section{Doi:10.5901/mjss.2014.v5n20p981}

\section{Abstract}

The authenticity of crafts/artifacts has been at the center of tourism debates for some time. There is disagreement among researchers on the conceptualization of the term. This paper contributes to clarifying the understanding of the concept by examining the authenticity of the Basotho hat (Mokorotlo) from the perspectives of weavers, corporative members, traditional leaders and street vendors at the Maseru and Maputsoe border posts, the main entry and exit points of Lesotho. The Basotho hat is an authentic product, and a popular artifact and memorabilia that is directly identified with Lesotho. It serves as both a cultural icon of Lesotho and part of the everyday attire of the Basotho people. The Basotho hat has gone through minor changes in response to local and tourist demands for new enhanced products. Lesotho is rich in cultural attractions that can be capitalized on to develop cultural tourism. The Lesotho Tourism Development Corporation, a destination management and marketing organization, can capitalize on products that are already popular with tourists to market it as part of cultural tourism. This has an added advantage to improve the livelihoods of impoverished Basotho. However, the government should implement mechanisms to certify the authenticity of hats for added appeal to tourists.

Keywords: authenticity, crafts, artifacts, Basotho hat, Lesotho, commodification.

\section{Introduction and Background}

Authenticity of cultural crafts and artifacts has received much attention in different parts of the world (Cohen, 1993, Littrell et al., 1993, Maruyama et al., 2008, Roland, 2010, Xie, 2011, Chang et al., 2012). Most research has only focused on the demand side, which includes the consumers or the tourists. This study attempts to fill the gap in our understanding of the issues of authenticity by examining the authenticity of the Basotho hat from the perspectives of the weavers and street vendors who are the producers and suppliers of the Basotho hat.

Like most other developing economies, the Lesotho government has prioritized tourism as an engine of economic growth and poverty alleviation (Lesotho Tourism Plan, 2006). Unlike most Southern African countries, Lesotho does not rely on wildlife as a key tourist attraction, and instead the country promotes its unique natural environment, which includes mountain scenery, topography, vegetation and cultural heritage attractions. Lesotho's unique high altitude and mountainous topography affords a distinctive scenic attraction, and no other location in Southern Africa offers a similar natural environment and features (Fabricius 2007, p. 6).

Tourism development in Lesotho is still at the exploratory stage (Manwa, 2012; Butler, 1980), which is evident by the contribution of tourism to the national economy. It is estimated that tourism contributes around 2\% of GDP and has an annual growth rate of $1.4 \%$, which is slower than the rest of the economy that is growing at $4.3 \%$ per annum (Lesotho Government, 2006). Cultural tourism is a multi-million dollar industry that accounts for over $40 \%$ of international travel (Richards \& van der Ark, 2013). Like other Southern African Development Community countries, Lesotho has prioritized tourism, especially cultural tourism, as a sustainable development option (Lesotho Tourism Plan, 2006). This provides the country an advantage to develop a tourism industry that is competitive, sustainable and benefits the local communities. Lesotho can capitalize on its culture and heritage by using these as add-on products to common tourist experiences, such as visiting the mountains, dams and other natural environments. Cultural and heritage tourism would greatly contribute towards promoting the sustainability agenda, as the people would be the owners and drivers of the product. More importantly, cultural tourism is a destination image, which is particularly important in tourists' decisions to travel (Frias et al., 2012). The cultural attractions in Lesotho are discussed in the following sections.

\subsection{Cultural Attractions of Lesotho}

Lesotho boasts a rich culture with a diversity of ethnic groups in various districts. For example, Quthing district includes 
three distinct ethic groups. The largest is the Basotho, which comprise $50 \%$ of the total population, followed by the Xhosa, which form $40 \%$ of the population. They have close links with the Xhosas in Eastern Cape in South Africa, and many have family ties across the border. Xhosa is the second most spoken language in South Africa. Their rich culture includes traditional dances, traditional dress and handicrafts, especially beadwork. Both men and women smoke long decorated pipes. Initiation schools are different from the Basotho's. The third largest ethnic group is the Baphuthi, which comprise the remaining 10\%. There are also other smaller tribes found in other districts, such as the Ndebeles, Batswana, and others (Lesotho Government, 2006; Coplan \& Quinlan, 1997). This provides for a rich mix of languages and cultures, as each group has its own customs, history, folklore and handicrafts.

Other cultural attractions include the royal historical route of Moshoeshoe I, the founder of the nation of Basotho. There are numerous Bushmen paintings, and the most impressive and well-preserved paintings are the Tsatane paintings in the Quthing district and a rock painting site on the banks of the Khohlo-Ntšo River (Cain, 2009).

Another important heritage site is Mount Moorosi, where the Baphuthi Chief Moorosi battled with the British at the end of the $19^{\text {th }}$ century and was eventually defeated. The dinosaur footprints are a major attraction in Moyeni. They were formed approximately 200 million years ago when several species of dinosaurs stepped on soft clay covered with earth and hardened to produce imprints (Lesotho Government, 2006). Other important heritage and historical sites include Liphofung Nature Reserve and the cave where King Moshoeshoe I stayed for an extended period with his army in the $19^{\text {th }}$ Century. Thaba-Bosiu village is particularly important as it was the stronghold of King Moshoeshoe I where he built his head office. The Catholic Church in Roma is another important heritage site as the first Catholic Church built in the Kingdom.

\subsection{The Basotho Hat (Mokorotlo)}

The Lesotho Tourism Development Corporation, the destination development and marketing organization for Lesotho, has branded the Basotho hat (Mokorotlo) and traditional blanket as iconic symbols of the country. The Basotho hat (Figure 1) is a conical-shaped straw hat made from an indigenous grass "mosea" (Ross, 1976). The Basotho hat is considered a part of Lesotho's national dress and is also seen on the national flag and currency. Lesotho is a country in which tradition is still very important, and the wearing of the distinctive Mokorotlo hat is still part of everyday life (Lesotho Government, 2006). This study analyzed the perceptions of the development of the Basotho hat and its importance in the cultural tourism landscape of Lesotho, due to the hat's iconic status.

Rosenberg (1999) notes that the Basotho hat gained prominence in the 20th century, when chiefs began to wear the hat and sing a song also known as Mokorotlo to garner support at village ("Pitso") gatherings. In its original form, it was exclusively worn by males to Pitsos. However, in the 1950s, new designs were developed to cater to women (Rosenberg 1999). It was also worn in the 1950s when there was new agitation in Africa that sought to put an end to colonial rule and gain independence. The hat became a way of linking politicians to Lesotho's traditional power structures, the chieftainship. Another important factor that strengthened the development of the Basotho hat as a national symbol was the association of the Mokorotlo with Lesotho's founder, King Moshoeshoe I (Rosenberg, 1999).

However, researchers have not yet explored the authenticity of the Basotho hat and its economic importance, especially on the livelihoods of Basotho. The study aims to bridge this gap by seeking perceptions of local people regarding the authenticity of the Basotho hat and the impact it has on their livelihoods.

The study was guided by two research questions:

- What are the producers and vendors' perceptions on the authenticity of the Basotho hat as a national symbol?

- What have been the social and economic impacts of the commercialization of the Basotho hat?

\section{Literature Review}

The next section reviews the literature on authenticity of artifacts/souvenirs. Authenticity as a concept has received much attention from researchers and has also been characterized by controversies and disagreements on the meaning of the concept (Lau, 2010). Varying and diverse interpretations of the term have been debated. Taylor (2001) concludes that there are as many definitions of authenticity as those who have written about it (Cohen, 1988; Hughes, 1995; Wang, 1999; Olsen, 2002; Beer, 2008).

There have been attempts at conceptualization of authenticity of crafts/souvenirs. Cohen (1993) proposed two methods of assessing authenticity of tourist art. First, the manufacturing processes should follow traditional methods. Second, the final product should be evaluated as to whether it represents the traditional product. Cohen's typology is also expounded on by the typology developed by Littrell et al. (1993). They suggest that souvenir authenticity can be 
examined in the context of uniqueness and originality; workmanship; aesthetics; function and use; cultural and historic integrity; craftsperson and materials; shopping experience; and genuineness.

Tourism is an intangible product (Beeton, 2006), and the only parts of the vacation that tourists can carry home with them are souvenirs of the places visited (Swanson \& Timothy, 2012). Souvenirs are a means of capturing the memory of a visited place, its subtle qualities and its special and unique aspects. As Swanson and Timothy (2012) propose, purchasing a souvenir is like carrying the destination home to showcase the special qualities of the visited place. As a result, souvenirs have become a major economic contributor to destinations (Timothy, 2005).

For souvenirs to play a significant role in economic impacts of destinations, they must be authentic. It has therefore been concluded that destinations that sell aboriginal arts are very popular with tourists because of the perceptions that the crafts sold are an authentic expression of aboriginal culture (Chang \& Wall, 2012).

As a result of controversies surrounding authenticity, Reisinger and Steiner (2008) concluded that the term authenticity should be discarded since there is no common ground on its meaning. This point is supported by Wall and Xie (2005), who proposed that research should move away from authenticity of objects and focus instead on determining who authenticates authenticity and why. The literature, however, confirms that the question of authenticity still remains a topic of interest to tourism researchers (Cohen, 2002; Belhassen et al., 2008; Mkono, 2012).

Several studies have also addressed authenticity in Africa. The main focus has been on cultural foods served in African restaurants from the perspective of tourists (Mkono, 2013). Other studies have focused on value chains where arts and crafts are included as part of tourist consumption (Mahony \& Van Zyl, 2002; Rogerson, 2007; Spencely \& Goodwin, 2007; Chirisa, 2009). Other African research has focused on how crafts can be used to improve livelihoods (Mbaiwa, 2011; Mbaiwa \& Stronza, 2012, Mbaiwa et al., 2008; Bins \& Ne,I 2002; Rogerson \& Sithole, 2001).

The literature reviewed shows that much research on the authenticity of souvenirs has been undertaken from the consumers' perspective. More research needs to be performed on the perceptions of the producers and suppliers of crafts as to what makes a craft souvenir authentic (Maruyama et al., 2008). This study aims to add to the literature on authenticity of indigenous crafts by examining the perceptions of producers on the authenticity of the Basotho hat.

\section{Methods}

This was a qualitative study to seek the views of the stakeholders in the weaving and selling of the Basotho hat. The qualitative design was found to be the most appropriate design for this study, because it was a way of understanding the meaning of the Basotho hat from people mostly in touch with the hat (Crosswell, 1998).

\subsection{Respondents}

Three employees of the Lesotho Tourism Development Corporation based at the Basotho hat building were interviewed to establish the structure, history and key players of the industry. We also wanted to establish the cost of buying a Basotho hat to determine the possible livelihood impact from selling the hats.

In-depth interviews were held with five experienced weavers and five cooperative members located in the BothaBothe District and three chiefs (traditional leaders). This is the area where most weaving of the Basotho hats takes place. Communities have also formed cooperatives specializing in the weaving and distribution of Basotho hats (Mokorotlo) to other parts of the country. Traditional leaders, chiefs from three villages, were interviewed to establish their perceptions on the significance of the hat from a cultural perspective. Structured interviews were also held with 20 street vendors at the Maseru main bus terminus, Maseru border post and Maputsoe border post. These sites were chosen, as they are the main entry and exit points for tourists visiting Lesotho. Vendors were chosen to validate views of the weavers regarding authenticity of the hat, as well as to determine which hats are popular and the price.

\subsection{Sampling and Procedures}

Convenience sampling was used to select the respondents. Only those vendors who were willing to be interviewed were interviewed. The study took place between December and February 2011 (street vendors) in Maseru. Street vendors in Maputsoe were interviewed in October and December 2012. The wholesalers (weavers) were interviewed in May and July 2011.

The interviews were translated into Sesotho, the local language. Two research students who were in the 4th year of university training were trained in interviewing techniques. Interview guidelines covered demographic information, Basotho hat designs, manufacturing processes, number of years they had been weaving the Basotho hat, reasons for 
selling the Basotho hat, number of years selling the hat, source of the hats, income generated from selling the hats, various designs and attitudes regarding genuineness of the hat, main customers and peak period when hats were sold. The interviews lasted for approximately 30 to 40 minutes. The interviews were tape recorded and transcribed verbatim. The main researcher is fluent in both Sesotho and English languages.

\subsection{Data Analysis}

Interviews were thematically analyzed (Braun \& Clarke, 2006). A second person in the university department who was familiar with the Sesotho language and knowledgeable about research methods was asked to review the data to confirm that the issues and findings of the study were all captured.

\section{Findings of the Study}

\subsection{Members of the Cooperative in Butha-Buthe}

The weavers were generally a middle age group, with an average age of 50 years. The highest educational qualification of the weavers was primary education.

\subsubsection{Manufacturing processes}

The raw material, the "Leholi" or "Mosea", which is the grass used for weaving the hat, is sourced from companies that buy it from harvesters in the highlands of Lesotho who then transport it to various outlets in the lowlands of Lesotho. Elders have transferred the art of weaving the hat from generation to generation. It was observed that the mastery of the weaving process was similar to an apprenticeship, in which the mentor certifies that the protégé has reached a stage whereby they can weave without supervision.

\subsubsection{The Major Hat Designs}

Over time, the Basotho hat has evolved into many designs, as shown in Figures 1-3. Figure 1 depicts a traditional Mokorotlo, which has more designs but fewer colors than the other hats shown in Figures 2 and 3. The weavers mentioned uncertainty as to what the original hat would have looked like. However, they emphasized that the current design, which they learned from their forefathers, is present in all designs of the Basotho hat. Over time, the weavers have experimented with new variations by adding different designs, which enhances the look of the hat.

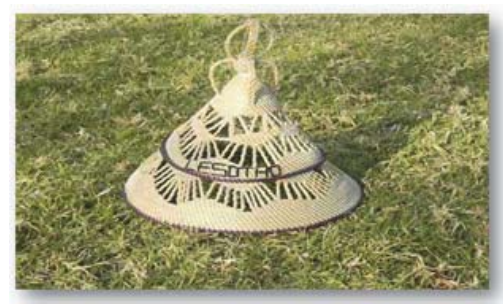

Figure 1: The Basotho hat (source: author's photos)

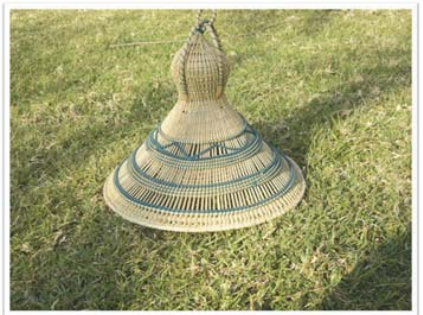

Figure 2: The Basotho hat with color added to the yarn used to saw the hat (source: author's photos) 
One other innovation has been the inscription of the word "Lesotho" on some hats, as a response to customers who wanted some form of certification that the hat was made in Lesotho. The original Lesotho hat did not have this label.

The weavers argued that all three hats were authentic, and the differentiating feature was price. Figure 3 was the least expensive and tended to be the most popular with tourists. The weavers confirmed that most tourists were not driven by design but by the price and that tourist did not seem to notice the complexities of the weaving in hats shown in Figures 1 and 2.

Figure 3 is the least expensive and most colorful. The weavers noted that it takes less time and energy to weave the hat in Figure 3. As a result, this is a fast selling hat, as it is less expensive compared to the other two hats.

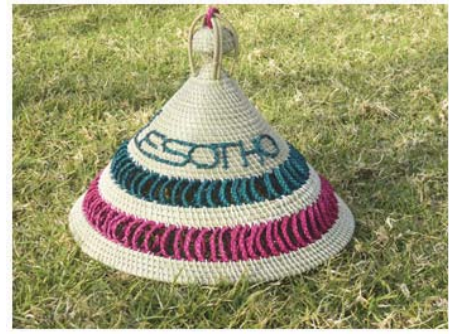

Figure 3: The least expensive Basotho hat (source: author's photos).

\subsubsection{Weavers' Main Market}

Weavers sell the hats to hawkers and individuals who visited their premises to buy the hats. Cooperative members benefit from the sale of hats in the form of shares from proceeds in selling the hats. Cooperatives have around 300 members/households who pay a small fee to join, around R30.00 (US\$1=R10.00).

Cooperative members were mainly men, as evidenced by only two women being interviewed. They pointed to the fact that the grass is "very sharp and can cut through your skin", hence very few women venture into weaving of the Basotho hat. The women interviewed at the site confirmed this statement. Cooperative proceeds complimented their other livelihoods strategies, which consisted of subsistence farming practices. They emphasized the importance of keeping cattle in the following words: ("monna ea senang likhomo hase monna"), which literarily means cattle define your manhood; your standing in society is defined by the number of cattle you own. They emphasized the prestige associated with owning cattle and self-sufficiency. One of the cooperative members went to the extent of bragging about her wealth. She told me that "Ke roile, ntlo eaka e tletse lijo, Lisiu li tletse poone, linaoa, mabele, litapole. Kena le masaka a mabeli a liphoofolo", indicates that she is very wealthy. She has all types of grain in her silos at home and two kraals are all full of cattle. All this wealth had been made possible by proceeds from the cooperative. Her two sons worked in the mines in South Africa and had contributed to some of her wealth.

Other cooperative members confirmed that the cooperative had made it possible for them to pay school fees and buy other necessities, which require cash. It complimented their other livelihoods.

\subsubsection{Customer Base}

The cooperative's main customers were vendors from different parts of Lesotho. They also had customers from South Africa who bought the hats in bulk for resale in South Africa. Although their main product was the traditional Basotho hat depicted in Figures 1-3, they also weaved other non-traditional hats, such as caps. Vendors were instrumental in suggesting newer fashion trends to be added to the Basotho hat designs.

\subsection{Traditional Leaders}

Traditional leaders, or chiefs, confirmed that Basotho express much pride in Mokorotlo, the Basotho hat. The hat is indeed important cultural attire that is worn to show national identity and pride. Most men would not attend a village gathering (Pitso) without wearing Makorotlo. 


\subsection{Street Vendors}

\subsubsection{Demographics of Street Vendors}

There were more female vendors (65\%) than male (35\%). The ages of vendors are reflected in Table 1 . The vendors comprised a middle age population, in which the majority were in the $41-50$ age groups (61\%). According to this study, individuals younger than 21 did not go into street vending, as only $4 \%$ of the population fell into this age bracket. Table 1 shows distribution by age group.

Table 1: Ages of street vendors

\begin{tabular}{|l|c|c|}
\hline Age Range & Frequency & Percentage \\
\hline $41-50$ & 8 & 41 \\
\hline $31-40$ & 7 & 35 \\
\hline $21-30$ & 4 & 20 \\
\hline Below 21 & 1 & 4 \\
\hline Total & $\mathbf{2 0}$ & 100 \\
\hline
\end{tabular}

The individuals who went into vending had received basic primary education (40\%). Surprisingly, there were also people who participated in vending with no formal education. Table 2 shows detailed educational background of the respondents.

Table 2: Educational attainment of street vendors

\begin{tabular}{|l|c|c|}
\hline Educational attainment & Frequency & Percentage \\
\hline Primary education & 8 & 40 \\
\hline No formal education & 5 & 28 \\
\hline Ordinary level & 4 & 20 \\
\hline Tertiary education & 3 & 12 \\
\hline Total & $\mathbf{2 0}$ & 100 \\
\hline
\end{tabular}

The vendors supported large households. Fifty percent supported 7-9 other family members, 33\% supported 4-6 other members of the household, and $17 \%$ supported more than 10 other members of the family.

\subsubsection{Reasons for Going into Selling Basotho Hats}

Several reasons were proposed as to why vendors went into selling Basotho hats. These are listed below in Table 3 in their order of importance. In most cases, there were multiple responses, in which a vendor mentioned more than one reason why they became vendors of Basotho hats. Thus, the figures in Table 3 do not add to 100 since interviewees mentioned more than one item. Under livelihoods option, we included: "selling the hats was the only means of looking after our families; selling the hats complemented other livelihoods". Under sustainability, we included people who went into vending because they saw the work as having long-term opportunities, since not only foreigners but also Basotho buy the hats. Under market driven we included those who said that "demand is very high for Basotho hat; you are never out of business; it attracts a lot of customers from different backgrounds and countries; it gives me the opportunity to meet interesting people who are prepared to pay a lot of money for Basotho hat; I have had people from other countries wanting to buy the hats; I am very good at persuading people to buy my hats."

Table 3: Reasons for vending

\begin{tabular}{|l|c|c|}
\hline Reason & Number & Percentage \\
\hline Livelihoods option & 20 & 100 \\
\hline Sustainability & 15 & 75 \\
\hline Nature of work & 10 & 50 \\
\hline Demand driven (sustainable market) & 10 & 50 \\
\hline
\end{tabular}




\subsubsection{Source of the Hats}

All but two vendors admitted to buying their hats from the weavers in Butha-Buthe. The two vendors said they were previously part of the cooperative in Butha-Buthe, but left the cooperative because it was not as financially rewarding as working independently. The majority who sourced the hats from the weavers noted they added a small mark-up to the hats. They could also determine if the customer was a local or tourist and adjusted prices accordingly, with cheaper prices for locals and slightly increased prices for foreigners.

\subsubsection{Vendor Customers}

The main customers were tourists coming from South Africa (60\%). Local Basotho made up 30\%. Only 10\% of the vendors said their customers were both Basotho and South Africans. All the vendors said that the best time to sell the hats was during the summer months of December to February. December was favored because it coincides with the Christmas holidays where many South Africans visit Lesotho. The sales were also good during South African holidays as many tourists use the holidays to visit Lesotho. These results are consistent with the National Plan's, which shows that the majority of tourists to Lesotho are from South Africa.

\subsubsection{Cost of the Basotho Hat}

The cost of the hat varies depending on the size and shape of the hat. The hat depicted in Figure 1 can be sold for R.150.00, Figure 2 for R100.00, and Figure 3 would go for R80.00. The top selling hat was the traditional Mokorotlo.

Substantial revenue is generated from the sale of Basotho hats especially during peak periods. The results are shown in Table 4. According to this table most vendors earn more than the minimum wage workers in the textile industry in Lesotho (R800.00 per month).

Table 4: Revenue generated through the sale of hats per month

\begin{tabular}{|c|c|c|}
\hline Revenue in Rands (R) & Number & Percentage \\
\hline 3000.00 & 7 & 37 \\
\hline 1500.00 & 5 & 24 \\
\hline 1200.00 & 4 & 20 \\
\hline 900.00 & 3 & 12 \\
\hline 800.00 & 1 & 7 \\
\hline Total & $\mathbf{2 0}$ & 100 \\
\hline
\end{tabular}

\section{Discussion}

The results show that the Basotho hat like all other cultural artifacts is not static. It has changed to address changing user needs and habits. The people of Lesotho hold the Basotho hat in high esteem as a national icon associated with Moshoeshoe I, the founder of the Kingdom of Lesotho. Secondly, commodification of the Basotho hat has been instrumental in empowering communities, alleviating poverty and enhancing cultural awareness in Lesotho and beyond (Sheyvens, 2003; Cole, 2007).

Another observation from the results is the difficulty in identifying the authentication process followed in the case of the Basotho hat (Cohen \& Cohen, 2012). The results show that cultural artifacts like the people's culture are dynamic (Wherry, 2006). The changes to the hat were cosmetic mainly to enhance the appearance of the hat (Maruyama et al., 2008). This is not unusual for cultural objects to change over time. Similar observations were made in Botswana for example, where the traditional baskets have changed in shape and design to represent changes in consumer tastes (Mbaiwa, 2004).

The results also show that with the high unemployment rate of over $45 \%$ and poverty levels of over $37 \%$ (Manwa, 2012), selling the Basotho hat has changed the livelihoods of poor communities. The trade has been able to complement other livelihoods strategies. In most cases, the income generated from selling the Basotho hats is much more than individuals would earn in formal employment, considering the fact that they have very little education. 


\section{Conclusion and Implications of the Study}

The study aimed at exploring the perceptions of producers on the authenticity of the Basotho hat. The results confirm that the Basotho hat is an authentic cultural artifact, which has been enhanced in design to attract consumers. The study also shows that commodification of the Basotho hat has empowered and improved the livelihoods of both the producers (weavers) and the street vendors.

Another conclusion from the study is that tourists are not necessarily driven by authenticity. In this case, as has been espoused by Belhassen et al., (2008) and also endorsed by MacCannell (2001), tourists are often driven by the desire to buy a hat that is fashionable rather than an authentic hat. The results are consistent with Cole's (2007) contention that authenticity is a Euro-centric concept that fails to recognize the interplay between culture and power, as well as the strategic development of tourism by the least developed communities to empower themselves.

The study has implications for the policy makers. The Lesotho Tourism Development Corporation (LTDC) can capitalize on the Basotho hat, which is already a known cultural product of Lesotho, by including it in the development of its cultural tourism. We noted from our interviews that there is call for branding the Basotho hat, guaranteeing that it is made and produced by Basotho. LTDC should be in the forefront of developing processes for certification of the authenticity of the Basotho hat.

\section{References}

Belhassen, V., Caton, K., Stewart, W.P. (2008). The search for authenticity in the pilgrim experience. Annals of Tourism Research, 35 (3), 668-689.

Beer, S. (2008). Authenticity and food experience- commercial and academic perspectives. Journal of Foodservice, 19 (3), 153-163.

Binns, T. and Nel, E. (2002). Tourism as a local development strategy in South Africa. Geographical Journal, 168, 235-247.

Braun, K. and Clarke, V. (2006). Using thematic analysis in Psychology. Qualitative Research in Psychology, 3 (2), 77-101.

Butler, R.W. (1980). The concept of a tourist area cycle of evolution, implications for management of resources. Canadian Geographer, $24(1), 5-123$.

Cain, C. (2009). Cultural heritage survey of Lesotho for the Maloti-Drakesberg Transfrontier Project, 2005-2006: Palaeontology, archaeology, history and heritage management. The South African Archaeological Bulletin, 64 (189), 33-44.

Chang, J., Wall, G. and Chang, C.L. (2008). Perceptions of the authenticity of Atayal woven handicrafts in Wulai. Taiwan Journal of Hospitality and Leisure Marketing, 16 (4), 385-409.

Chang, J., Wall, G. and Hung, J.R. (2012). Tourists' perceptions of aboriginal heritage souvenirs. Asia Pacific Journal of Tourism Research, 17 (6), 684-700.

Chirisa, I. (2009). The geography of informal sector operations (ISOs): A perspective of urban Zimbabwe. Journal of Geography and Regional Planning, 2(4), 66-79.

Cohen, E. and Cohen, S.A. (2012). Authentication: hot or cool. Annals of Tourism Research, 39 (3), 1295-1314.

Cohen, E. (2002). Authenticity, equity and sustainability in tourism. Journal of Sustainable Tourism, 10 (4), 267-276.

Cohen, E. (1993). The heterogenization of a tourist art. Annals of Tourism Research, 20(1), 138-163.

Cohen, E. (1992). Pilgrimage centres: concentric and excentric. Annals of Tourism Research, 19, 33-50.

Cohen, E. (1988). Authenticity and commoditization in tourism. Annals of Tourism Research, 15(3), 371-86.

Cole, S. (2007). Beyond authenticity and commodification. Annals of Tourism Research, 34 (4), 943-960.

Coplan, D.B. and Quinlan, T. (1997). A chief by the people: Nation versus state in Lesotho. Africa: Journal of International African Institute, 67 (1), 27-60.

Creswell, W.J. (1998). Qualitative inquiry and research design: choosing among five traditions. Sage Publications: Thousand Oaks, CA.

Fabricius, M. (2007). Tourism, Towards 2020: A strategic plan for Tourism development in Lesotho. Maseru: Lesotho.

Frias, D.M. Rodriguez, M.A. Castaneda, A. Sabiote, C.M. and Buhalis, D. (2012). The formation of a tourist destination's image via information sources: the moderating effect of culture. International Journal of Tourism Research, 14, 437-450.

Haldrup, M. and Larsen, J. (2006). Material cultures of tourism. Leisure Studies, 25 (3), 275-289.

Hughes, G. (1995). Authenticity in Tourism. Annals of Tourism Research, 22, 181-183.

Lau, R.W.K. (2010). Revisiting authenticity. A social realist approach. Annals of Tourism Research, 37 (2), 478-498.

Lesotho Tourism Plan, 2006. Maseru: Lesotho Government.

Lesotho Government. 2006. Support to institutional and capacity strengthening of the tourism sector. Report on priority areas. Maseru: Government of Lesotho; United Nations, Development Programme UN World Tourism Organization.

Littrell, A.M., Anderson, FL., Brown, J.P. (1993). What makes a craft souvenir authentic? Annals of Tourism Research, 20 (1), 197-215.

Mahony, K. and Van Zyl, J. (2002). The impacts of tourism investment on rural communities: Three case studies in South Africa. Development Southern Africa, 19 (1), 83-103.

Manwa, H. ( 2012). Communities' understanding of tourists and the tourism industry: The Lesotho Highlands Water project. African Journal of Business Management, 6(22), 6667-6674.

Maruyama, N.U., Yen, T., Stronza, A. (2008). Perception of authenticity of tourist art among Native American artists in Santa Fe, New 
Mexico. International Journal of Tourism Research, 10, 453-466.

Mbaiwa, J.E. (2004). Prospects of basket production in promoting sustainable rural livelihoods in the Okavango Delta, Botswana. International Journal of Tourism Research, 6 (4), 221-235.

Mbaiwa, J. (2011). Changes on traditional livelihood activities and lifestyle caused by tourism development in the Okavango Delta, Botswana. Tourism Management, 32,1050-1060.

Mbaiwa, J. and Stronza, A.L. (2010).The effects of tourism development on rural livelihoods in the Okavango Delta, Botswana. Journal of Sustainable Tourism, 18 (5), 635-656.

Mbaiwa, J., Ngwenya, B.N., Kgathi, D.L. (2008). Contending with unequal and privileged access to natural resources and land in the Okavango Delta, Botswana. Singapore Journal of Tropical Geography, 29 (2), 155-172.

Mkono, M. (2013). African and Western tourists' object authenticity quest? Annals of Tourism Research, 41,195-214.

Mkono, M. (2011). Authenticity does matter. Annals of Tourism Research, 39 (1), 480-502.

Olsen, K. (2002). Authenticity as a concept in tourism research: the social organisation of the experience of authenticity. Tourism Studies, 2 (2), 159-182.

Reisinger, Y. and Steiner, C. J. (2006). Reconceptualising object authenticity. Annals of Tourism Research, 33 (1), 65-86.

Richards, G. and van der Ark, L.A. (2013). Dimensions of cultural consumption among tourists: Multiple correspondence analysis. Tourism Management, 37, 71-76.

Rogerson, C.M. (2007). Tourism routes as vehicles for local economic development in SouthAfrica: The example of the Magaliesberg Meander. Urban Forum, 18 (2), 49-68.

Rogerson, C. M. and Sithole, P. M. (2001). Rural handicraft production in Mpumalanga, South Africa: Organisation, problems and support needs. South African Geographical Journal, 83 (2), 149-158.

Roland, L.K. (2010). Tourism and the commodification of Cubanidad. Tourism Studies, 10 (3), 3-18.

Rosenberg, S. (1999). The evolution of a symbol: Mokorotlo and national identity in Lesotho. Review of Southern African Studies, 3 (2), 37-60.

Ross, D. (1976). Culture and decorative arts of Africa. African Arts, 9 (4), 76-77.

Scheyvens, R. (2003). Tourism for development, empowering communities. New Jersey:Prentice Hall.

Spenceley, A. and Goodwin, H. (2007). Nature-based tourism and poverty alleviation: impacts of private sector and parastatal enterprises in and around Kruger National Park, South Africa. Current Issues in Tourism, 10 (2-3), 255-277.

Timothy, D. J. (2005). Shopping tourism, retailing and leisure. Clevedon: Channel View.

Swanson, K. K. and Timothy, D.J. (2012). Souvenirs: Icon of meaning, commercialization and commoditization. Tourism Management, 33, 489-499.

Taylor, J.P. (2001). Authenticity and sincerity in tourism. Annals of Tourism Research, 28(1), 7-26.

Xie, P.F. (2011). Authenticating ethnic tourism. Bristol, Buffalo, Toronto, Channelview Publications.

Wall, G. and Xie, P.F. (2005). Authenticating ethnic tourism: Li dancers' perspectives. Asia Pacific Journal of Tourism Research, 10 (1), $1-21$.

Wang, N. (1999). Rethinking authenticity in tourism experience. Annals of Tourism Research, 26(2), 349-70.

Wherry, F. F. (2006). The social sources of authenticity in global handicraft markets evidence from northern Thailand. Journal of Consumer Culture, 6(1), 5-32. 